\title{
Identifikasi Ancylostoma spp., dan Trichuris spp. pada Anjing Pemburu di Kenagarian Sungai Kamuyang, Kecamatan Lareh Sago Halaban, Limapuluh Kota, Sumatra Barat
}

\author{
Identification of Ancylostoma spp. and Trichuris spp. Hunting Dogs in the \\ Kamuyang River Kenagarian, Lareh Sago Halaban, \\ Limapuluh Kota, West Sumatra
}

\author{
Ilviga Anggraini Putri ${ }^{*}$, Prima Silvia Noor ${ }^{2}$, Engki Zelpina ${ }^{2}{ }^{1}$, Sujatmiko ${ }^{2}$ \\ ${ }^{1}$ Mahasiswa Program Studi Paramedik Veteriner, Politeknik Pertanian Negeri Payakumbuh \\ ${ }^{2}$ Program Studi Paramedik Veteriner, Politeknik Pertanian Negeri Payakumbuh, \\ Jl. Raya Negara, KM 7 Tanjung Pati, Harau, Limapuluh Kota, 26271 \\ *E-mail: ilvigaanggraini@gmail.com
}

\begin{abstract}
ABSTRAK
Anjing (Canis familiaris) adalah hewan yang sangat dekat berinteraksi dengan manusia. Selain sebagai hewan kesayangan anjing juga sering dimanfaatkan sebagai hewan pemburu. Salah satu penyakit parasitik yang sering menjadi permasalahan pada anjing pemburu adalah penyakit cacingan yang disebabkan oleh nematoda saluran pencernaan (gastrointestinal nematodes) yaitu Ancylostoma spp. dan Trichuris spp. yang dapat menyebabkan ancylostomiasis dan trichuriasis. Tujuan penelitian ini adalah untuk mengetahui infeksi Ancylostoma spp. dan Trichuris spp. serta prevalensi pada anjing pemburu. Penelitian ini merupakan penelitian observasional yang dilakukan secara cross sectional. Sampel yang diambil sebanyak 50 feses anjing pemburu dan diperiksa menggunakan metode uji apung. Hasil penelitian ini menunjukkan, bahwa 31 sampel feses anjing pemburu positif terinfeksi oleh nematoda dengan prevalensi 62\% yang terdiri dari Ancylostoma spp. 52\%, Trichuris spp. 6\% dan infeksi ganda (Ancylostoma spp. dan Trichuris spp) sebesar 2\%.
\end{abstract}

Kata kunci: Anjing pemburu, Ancylostoma spp. Nematoda, Trichuris spp.

\begin{abstract}
Dogs are animal that interact very closely with humans. Apart from being a pet, dogs are also often used as hunting animals. One of the parasitic diseases that often becomes a problem in hunting dogs is intestinal worms caused by gastrointestinal nematodes, namely Ancylostoma spp. and Trichuris spp. which can cause hookworm infection and trichocephalosis. The aim of this study was to determine the infection with Ancylostoma spp. and Trichuris spp. and prevalence among hunting dogs. This study is a cross-sectional observational study. Up to 50 faeces from hunting dogs were taken and examined by floating tests. The results of this study indicated that 31 faecal samples from hunting dogs were infected with a $62 \%$ prevalence of nematodes consisting of Ancylostoma spp. 52\%, Trichuris spp. $6 \%$ and multiple infections (Ancylostoma spp. and Trichuris spp) $2 \%$.
\end{abstract}

Key Words: Ancylostoma spp., Hunting dog, Nematodes, Trichuris spp., 


\section{PENDAHULUAN}

Anjing (Canis familiaris) adalah hewan yang sangat dekat berinteraksi dengan manusia. Anjing memiliki ras terbanyak dan memiliki perbedaan antara satu dengan yang lain sehingga mendorong manusia untuk memberi perhatian yang lebih. Selain hewan kesayangan anjing sering juga dimanfaatkan untuk penjaga rumah, hewan pemburu dan sebagai hewan percobaan (Dharmojono, 2003; Akhira et al., 2013).

Anjing pemburu walaupun dipelihara dengan baik belum tentu bebas dari infeksi penyakit baik yang disebabkan oleh bakteri, virus, protozoa, maupun cacing. Salah satu penyakit parasitik yang sering menjadi permasalahan adalah penyakit cacingan yang disebabkan oleh nematoda saluran pencernaan (gastrointestinal nematodes) (Hanafiah et al., 2002). Berbagai genus nematoda dapat hidup pada saluran pencernaan anjing seperti golongan Ascaris (Ascaris sp., Toxocara cati, Toxocara canis dan Toxascaris leonina), Trichuris sp., Capillaria sp., Trichostrongilus sp., Strongylus sp., dan Ancylostoma spp. (Urquhart et al., 2000; Bowman et al., 2003). Cacing ini umumnya menular melalui tanah pada saat anjing beraktivitas dan memperoleh makanan. Berbagai jenis hewan yang menjadi inangnya meliputi hewan ternak, hewan kesayangan, dan satwa liar (Sudhaus dan Fitch, 2001; Arifin et al., 2019).

Prevalensi cacing nematoda gastrointestinal pada anjing pemburu di Kecamatan Lareh Sago Halaban sebanyak $57,14 \%$ positif adanya telur cacing nematoda, terinfeksi jenis cacing
Ancylostoma spp., Uncinaria spp., dan Toxocara spp. dengan kondisi infeksi tunggal, ganda dan multiinfeksi. Dampak dari infeksi cacing pada anjing pemburu mengakibatkan penurunan stamina dan bobot badan anjing pemburu. Anjing yang cacingan akan menunjukan gejala seperti batuk, diare berdarah, muntah, lesu, dan tidak aktif, kehilangan nafsu makan, perut membuncit, bulu kusam dan tidak bercahaya, gatal-gatal atau iritasi kulit (Akhira et al., 2013).

Kejadian penyakit cacingan pada anjing pemburu dipengaruhi oleh tiga faktor yang saling terkait yakni agen penyebab, inang (host), dan faktor lingkungan yaitu kondisi di luar tubuh inang yang mendukung terhadap munculnya kasus cacingan. Prevelensi anjing yang terinfeksi parasit nematoda juga perlu diketahui untuk melihat seberapa luas infeksi cacing nematoda di suatu daerah. Penelitian ini bertujuan untuk mengetahui Ancylostoma spp. dan Trichuris spp. yang menginfeksi saluran pencernaan anjing pemburu di Kanagarian Sungai Kamunyang, Lareh Sago Halaban, Sumatera Barat.

\section{BAHAN DAN METODE}

Sampel pada penelitian ini berupa 50 feses anjing pemburu yang diperoleh dari beberapa Jorong yang berada di Kenagarian Sungai Kamuyang, Kecamatan Lareh Sago Halaban, Kabupaten Limapuluh Kota, yaitu Pengambilan sampel feses anjing pemburu diambil langsung ke tempat pemilik anjing Pemburu di Kenagarian Sungai Kamuyang. 
Tabel 1. Sampel yang diambil tidak memperhatikan umur, jenis ras, jenis kelamin dan sistem pemeliharaan.

\begin{tabular}{lc}
\hline Lokasi Pengambilan Sampel & Jumlah Sampel (ekor) \\
\hline Jorong Batang Tabik & 5 \\
Jorong Tanjuang Kaliang & 5 \\
Jorong Tabiang & 6 \\
Jorong Subaladuang & 6 \\
Jorong Nangkodok & 5 \\
Jorong Rageh & 6 \\
Jorong XII Kampuang & 6 \\
Jorong VIII Kampuang & 5 \\
\hline \multicolumn{1}{c}{ Total } & 50 \\
\hline
\end{tabular}

Pemeriksaan sampel dilakukan dengan uji apung sampel feses dimasukkan ke dalam mortar sebanyak 2 gram, ditambah aquades dan diaduk sampai homogen. Kemudian dituangkan ke dalam tabung sentrifus sampai setinggi $3 / 4$ tabung. Sentrifus dilakukan dengan kecepatan 2000 RPM selama 5 menit. Selanjutnya, cairan jernih di atas endapan dibuang, dan ditambahkan larutan $\mathrm{NaCl}$ jenuh. Tabung disentrifus kembali dengan kecepatan 2000 RPM selama 5 menit. Tabung sentrifus diletakkan di atas rak dengan posisi tegak lurus, diteteskan $\mathrm{NaCl}$ jenuh dengan pipet sampai permukaan cairan di dalam tabung menjadi cembung dan dibiarkan selama 3 menit, tempelkan object glass di atas permukaan yang cembung tadi dengan hati-hati lalu cepatcepat dibalik. Permukaan object glass ditutup dengan menggunakan cover glass dan diperiksa di bawah mikroskop dengan pembesaran 100× (Soulsby, 1982).

\section{HASIL DAN PEMBAHASAN}

Hasil pemeriksaan 50 sampel feses anjing pemburu dari lokasi tempat pengambilan sampel di Kenagarian Sungai Kamuyang, Lareh Sago.

Halaban, Limapuluh Kota, Sumatera Barat ditemukan dua jenis telur nematoda yaitu Ancylostoma spp. dan Trichuris spp (gambar 1). Total prevalensi nematoda pada sampel feses anjing adalah 62\% yang terdiri dari Ancylostoma spp. 52\%, Trichuris spp. 6\% dan infeksi ganda (Ancylostoma spp. Trichuris spp.) sebesar $2 \%$ (tabel 2). 


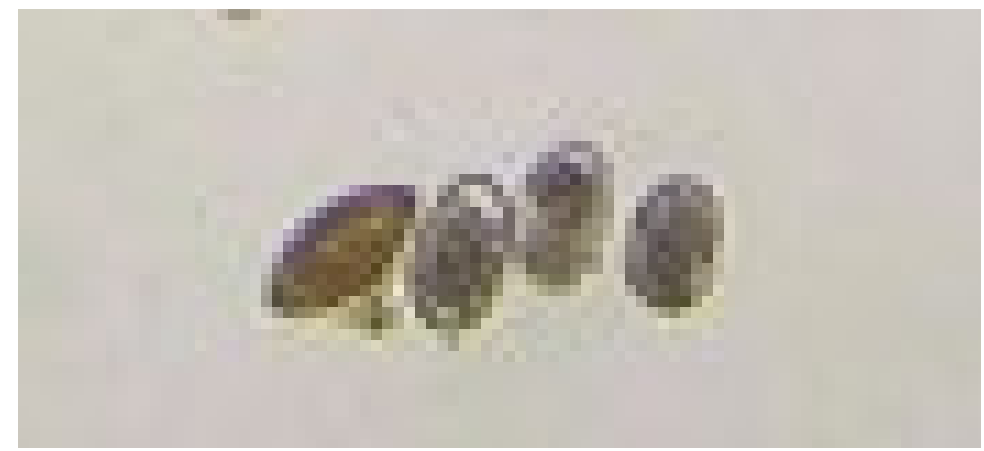

Gambar 1. Kiri Trichuris spp. dan kanan Ancylostoma spp.

Tabel 2. Prevalensi nematoda pada feses anjing pemburu

\begin{tabular}{lccc}
\hline \multirow{2}{*}{ Sampel } & \multicolumn{3}{c}{ Nematoda } \\
\cline { 2 - 4 } & Ancylostoma spp. & Trichuris spp. & Infeksi ganda \\
\hline Feses anjing 50 sampel & 27 & 3 & 1 \\
\hline Prevalensi jenis infeksi (\%) & 52 & 6 & 2 \\
\hline Prevalensi total (\%) & & 62 & \\
\hline
\end{tabular}

Berdasarkan hasil penelitian sebelumnya pada anjing Kintamani di Desa Sukawana, Kintamani, Bangli dan di Provinsi Bali ditemukan Ancylostoma spp. dan Trichuris spp. dengan prevalensi 55.55\% dan 0,87\% (Putera 2015; Agustina et al., 2021). Laporan kejadian infeksi di negara lain dilaporkan di Thailand ditemukan Ancylostoma spp. dengan prevalensi $26.4 \%(79 / 299)$ dan 10,38\% (22/212) (Kladkempetch et al., 2020) sedangkan infeksi Trichuris spp. di Bangkok dengan prevalensi 20,5\% dan Kota Sassari dan Alghero di Italia dengan prevalensi 0,6\% dan 2,3\% (Inpankaew et al., 2007; Tamponi et al., 2020)

Telur cacing yang dominan menginfeksi anjing pemburu pada penelitian ini adalah Ancylostoma spp. (52\%), Adapun spesies umum yang menginfeksi anjing adalah Ancylostoma caninum, A. ceylanicum, A. braziliense, dan
Uncinaria stenocephala,sedangkan yang menginfeksi kuving adalah Ancylostoma braziliense, A tubaeforme, A. ceylanicum, dan Uncinaria stenocephala (Bowman et al., 2010; Liu et al., 2015).

Ancylostoma spp. dan Trichuris spp. dapat menyebabkan ancylostomosis dan trichuriasis yang menyebabkan penyakit pada anjing dan kucing, biasanya disebabkan oleh Ancylostoma caninum, Ancylostoma braziliense dan Trichuris vulpis. Parasit ini umumnya terjadi di usus, sekum dan colon (Urquhart et al., 2000; Traversa 2014). Ancylostomiasis dapat menginfeksi anjing pada berbagai umur, makin tua umur anjing makin resisten terhadap infeksi cacing sehingga persentase kejadian ancylostomiasis pada anjing muda lebih tinggi dibandingkan anjing dewasa (Georgi dan Georgi, 1990). Spesies A. caninum, parasit dari kelas nematoda, dikenal sebagai cacing usus 
penghisap darah dan merupakan penyebab utama penyakit cacing tambang pada anjing di daerah tropis dan subtropis di dunia (Liu et al., 2013).

Trichuris spp., dikenal sebagai cacing cambuk yang telah menjadi parasit pada banyak spesies peliharaan termasuk anjing, kucing dan hewan ternak lainnya yang dapat menyebabkan enteritis, diare, dan penurunan berat badan. Spesies $T$. vulpis merupakan cacing nematoda yang tersebar luas di seluruh dunia. Pada infeksi berat dapat menyebabkan peradangan pada usus, diare bercampur darah dan lendir, ikhterus dan bisa menyebabkan kematian (Areekul et al., 2010).

\section{KESIMPULAN}

Dari penelitian yang telah dilakukan ditemukan nematoda pada feses anjing pemburu di Kenagarian Sungai Kamuyang, Lareh Sago Halaban, Limapuluh Kota, Sumatera Barat dengan prevalensi $62 \%$ dengan jenis infeksi tunggal (Ancylostoma spp., 52\% dan Trichuris spp., 6\%) dan infeksi ganda (Ancylostoma spp. Dan Trichuris spp) sebesar 2\% karena berpotensi zoonosis sehingga para pencinta anjing perlu memperhatikan manajemen kesehatan dalam pemeliharaannya.

\section{DAFTAR PUSTAKA}

Agustina, K.K., M.S. Anthara, N.A.A.N. Sibang, W.A.R. Wiguna, J.K. Apramada, W.N.F. Gunawan, I.B.M. Oka, M. Subrata and N.K. Besung. 2021. Prevalence and distribution of soil transmitted helminth infection in free-roaming dogs in Bali Province, Indonesia, Vet World, 14(2): 446-451
Akhira, D., Y. Fahrimal dan M. Hasan. 2013. Identifikasi Parasit Nematoda Saluran Pencernaan Anjing Pemburu (Canis familiaris) di Kecamatan Lareh Sago Halaban Provinsi Sumatera Barat. Jurnal Medika Veterinaria 7: 42-45.

Arifin, K., Kusnoto, A. Yudhana, A. Sunarso, M.T.E. Purnama dan R.N. Praja. 2019. Prevalensi Haemonchiasis Pada Kambing Peranakan Etawah di Kecamatan Kalipuro, Banyuwangi. J. Med. Vet., 2(2):108-111

Areekul, P., C. Putaporntip, U. Pattanawong, P. Sitthicharoenchai, and S. Jongwutiwes. 2010. Trichuris vulpis and $\mathrm{T}$. trichiura infections among schoolchildren of a rural community in Northwestern Thailand: The possible role of dogs in disease transmission. Asian Biomed. 4(1): 49-60.

Bowman, D.D., S.C. Barr, C.M. Hendrix, D.S. Lindsay. 2003. Gastro-Intestinal Parasites of Cats International Vaterinary Information Service Ithaca New York, USA.

Bowman, D.D., S.P. Montgomery, A.M. Zajac, M.L. Eberhard, K.R. Kazacos. 2010. Hookworms of dogs and cats as agents of cutaneous larva migrans. Trends Parasitol. 26:162-167.

Dharmojono. 2003. Anjing Permasalahan Dan Pemecahan. Jakarta: Penebar Swadaya

Georgi, J.R, and M.R. Georgi. 1990. Parasitology for Vetrinarians. $5^{\text {th }}$ ed. W.B Sounders Company. London Hanafiah, M., Winaruddin, and Rusli. 2002. Studi Infeksi Nematoda 
Gastrointestinal pada Kambing dan Domba di Rumah Potong Hewan Banda Aceh = Study of Gastrointestinal Nematodes Investing Goats and Sheep at the Banda Aceh Slaughterhouse. Jurnal Sains Veteriner 20(1):15-19.

Inpankaew, T., R. Traub, R.C.A. Thompson, Y. Sukthana. 2007. Canine Parasitic Zoonoses In Bangkok Temples. Southeast Asian J Trop Med Public Health. 38(2):247255.

Kladkempetch, D., S. Tangtrongsup, and S. Tiwananthagorn. 2020. Ancylostoma ceylanicum: The Neglected Zoonotic Parasite of Community Dogs in Thailand and Its Genetic Diversity among Asian Countries. Animals, 10, 2154:1-15

Kusumamihardja, S. 1992. Parasit dan Parasitosis pada Hewan Ternak dan Hewan Piaraan. Bogor, IPB: Pusat Antar Universitas.

Liu, Y., G. Zheng, M. Alsarakibi, X. Zhang, W. Hu, P. Lu, L. Lin, L. Tan, Q. Luo, and G. Li. 2013. Molecular identification of Ancylostoma caninum isolated from cats in southern China based on complete its sequence. Biomed Res Int. 868050. doi:10.1155/2013/868050

Liu, Y.J., G.C. Zheng, P. Zhang, M. Alsarakibi, X.H. Zhang, Y.W. Li, T. Liu, S.N. Ren, Z.X. Chen, and Y.L. Liu. 2015. Molecular identification of hookworms in stray and shelter dogs from Guangzhou city, China using its sequences. J. Helminthol. 89:196202.

Putera, P.A.A. 2015. Prevalensi Infeksi Cacing Ancylostoma spp. pada Anjing Kintamani Bali di Desa Sukawana Kecamatan Kintamani Kabupaten
Bangli Bali. (Skripsi). Denpasar: Universitas Udayana.

Soulsby, E.J.L. 1982. Helminth, Arthropods and Protozoa of Domesticated Animals. 7th ed. London: Bailliere Tindall.

Sudhaus, W., and D. Fitch. 2001. Comparative Studies on the Phylogeny and Systematics of the Rhabditidae (Nematoda). J. Nematol., 33:1-70.

Tamponi, C., S. Knoll, G. Tosciri, F. Salis, G. Dessi, M.G. Cappai, A. Varcasia, A. Scala. 2020. Environmental Contamination by Dog Feces in Touristic Areas of Italy: Parasitological Aspects and Zoonotic Hazards. Am. J. Trop. Med. Hyg., 103(3): 1143-1149

Traversa, D., A.F. di Regalbono, A. Di Cesare, F. La Torre, J. Drake, M. Pietrobelli. 2014. Environmental Contamination by Canine Geohelminths. Parasit Vectors 7: 67.

Urquhart, G. M., J. L. Armor, A. M. Duncan and F. M. Jennings. 2000. In: Veterinary Parasitology. 3rd (ed). ELBS Longman, UK. pp: 50-51: 274276. 